\title{
Association of Vitamin D receptor gene $B s m I$ polymorphism with type 2 diabetes mellitus in Pakistani population
}

\author{
Hussain Fatma ${ }^{1}$, Sattar Naila Abdul ${ }^{2}$
}

1. Department of Biochemistry, Faculty of Sciences, University of Agriculture, Faisalabad, Pakistan. Email:fatmauaf@yahoo.com

2. Department of Biochemistry, Government College for Women University, Faisalabad, Pakistan.

Email: uaf_naila_sattar@yahoo.com

\begin{abstract}
Background: Type 2 diabetes mellitus (T2DM) is a complex metabolic disorder with strong genetic components. The reported association of vitamin D receptor (VDR) gene polymorphisms varies among ethnic groups.

Objectives: The present study was conducted to determine association of vitamin D receptor gene Bsm $\mathrm{I}(\mathrm{rs} 1544410 \mathrm{~A}>\mathrm{G})$ polymorphism with type 2 diabetes mellitus in Pakistani population.

Methods: Blood samples were collected from 150 T2DM patients and 100 non-diabetic engaged by convenient sampling method. After collection of demographic data, assessment of fasting glucose (FG), vitamin D, HbA1c, renal function tests, liver function tests and lipid profile was done. Candidate gene polymorphism was analyzed by DNA amplification with polymerase chain reaction and endonuclease digestion.

Results: Biochemical parameters were significantly different among case and control groups. Associations of Bsm I genotype with T2DM, related complications and biochemical variables were not significant.

Conclusion: The current study did not provide evidence for the association of VDR gene BsmI polymorphism with T2DM in Pakistani population.
\end{abstract}

Keywords: Vitamin D receptor gene; single nucleotide polymorphism; type 2 diabetes mellitus.

DOI: https://dx.doi.org/10.4314/ahs.v19i2.41

Cite as: Fatma H, Abdul SN. Association of vitamin D receptor gene BsmI polymorphism with type 2 diabetes mellitus in Pakistani population. Afri Health Sci.2019;19(2): 2164-2171. https:/ / dx.doi.org/10.4314/abs.v19i2.41

\section{Introduction}

Type 2 diabetes mellitus (T2DM) is a complex metabolic disorder with strong genetic components. Candidate genes and variants for T2DM risk present in specific genome parts are involved in disease onset, associated pathways and functions. ${ }^{1,2}$

Single nucleotide polymorphisms (SNP) in vitamin D receptor (VDR) gene modulate glucose intolerance, insulin secretion and sensitivity. ${ }^{3-5}$ Genetic polymorphism of vitamin D receptor (VDR) gene can affect insulin secretion, causing insulin resistance, affect vitamin D syn-

\section{Corresponding author:}

Hussain Fatma,

Department of Biochemistry, Faculty of Sciences, University of Agriculture, Faisalabad, Pakistan.

Email: fatmauaf@yahoo.com thesis, transportation and action. ${ }^{6}$ VDR gene located on chromosome $12 \mathrm{q} 12-\mathrm{q} 14$ mediates vitamin $\mathrm{D}$ action as it binds to vitamin $\mathrm{D}$ response elements (VDRE). ${ }^{7-9}$

Vitamin D binding protein (DBP) is the gene product that mediates vitamin D action. Cholcalciferol enters blood stream through binding to DBP. VDR gene genotype $B s m \mathrm{I}$ polymorphism found in intron 8is related with onset of type 2 diabetes mellitus. ${ }^{10,11}$ Al-Daghri et al. ${ }^{12}$ stated that Bsm I SNP is significantly more common in T2DM patients. Other reports also demonstrated analogous relationship between BsmI polymorphism and T2DM in different populations. ${ }^{13-16}$ Consequently, association between Bsm I SNP and risk of T2DM in different ethnic groups is not conclusive.

SNP relates to disease susceptibility and response to treatment. ${ }^{17}$ Hypovitaminosis $\mathrm{D}$ has been reported among $\mathrm{Pa}-$ kistani population. ${ }^{18-20}$ However, researchers overlooked the role of VDR gene SNP in local population especially 
with reference to diabetes mellitus. Progress in identification of novel VDR gene variants predisposing to diabetes mellitus in Pakistan has been limited. Therefore, current research was conducted to assess the association of VDR gene BsmI polymorphism with T2DM in Pakistani population.

\section{Methods}

\section{Research design}

Study was conducted from March, 2015 to January, 2016 at Clinico-Medical Biochemistry Lab., Department of Biochemistry, University of Agriculture, Faisalabad, Pakistan and Molecular Labs., Department of Medical and Dentistry, Southmead Hospital, University of Bristol, Bristol, United Kingdom. Sampling was conducted within Pakistan and included consented 150 T2DM patients and 100 non-diabetic engaged by convenient sampling method. Graduates Studies and Research Board (GSRB), University of Agriculture, Faisalabad, Pakistan granted ethical approval.

\section{Sample collection and bioassays}

After collection of demographic data,fasting blood samples were taken in EDTA-coated vacutainers.Assessment of fasting glucose (FG), vitamin $\mathrm{D}, \mathrm{HbA1c}$, renal function tests,liver function tests and lipid profile was done by kits (Merck, Germany) as per manufacturer's guidelines using Dade Behring clinical chemistry system(dimension auto-analyzer, Siemens, USA) and Diastat auto-analyzer (Randox, UK).

\section{DNA extraction and quantification}

After genomic DNA extraction, the quantity and quality of DNA was assessed by Nanodrop (Nanophotometer $^{\mathrm{TM}}$, Implen, Germany). Purity of the DNA was assessed by measuring optical density (OD) as OD260/ OD280. ${ }^{22}$

\section{PCR-RFLP}

Polymerase chain reaction (PCR) primers sequences used were: (F: CCCTGGCACTGACTCTGCTC; R: GGAAA-
CACCTTGCTTCTTCTCC) as described earlier. ${ }^{14,23}$ Go Taq kit (Promega Madison, Wisconsin USA) was used for about $1.0 \mathrm{~mL}$ of genomic DNA (100 $\mathrm{ng} / \mu \mathrm{L})$. PCR conditions were optimized for annealing temperature $\left(60{ }^{\circ} \mathrm{C}\right)$ and $\mathrm{Mg}^{2+}$ concentration. The intron 8 was amplified to study the BsmI polymorphism(PCR thermocycler T100TM, BioRad). Using RFLP (restriction fragment length polymorphism) method, fragments were digested to assess the BsmI (rs1544410 A>G) genotype (New England BioLabs ${ }^{\circledR}$, R0109S). A molecular weight marker (HyperLadder II, Bioline or VC 100 bp Plus DNA Ladder, Vivantis) and for agarose gel visualization, UV light (UVITEC system, Uvitec Cambridge) were used. ${ }^{14}$

All data was expressed as mean \pm SD (standard deviation), $\%$ or $\mathrm{n}$ (number). Data analysis was performed using Statistical Package for Social Sciences (version 17; Chicago, USA). P value less than 0.05 was considered significant.

\section{Results}

\section{Biochemical assays}

Results are presented in table 1. Elevated FG, HbA1c, BMI, blood pressure and decreased vitamin $\mathrm{D}(\mathrm{P}<0.05)$ levels were evident in case group as compared to controls with negative correlation between vitamin $\mathrm{D}$ and $\mathrm{HbA} 1 \mathrm{c}$. Liver function tests inferences were similar among both groups. Regarding RFTs and lipid profile, T2DM sample showed appreciably $(\mathrm{P}<0.05)$ higher concentrations than control participants. Within the each group, associations of biochemical variables with vitamin $\mathrm{D}$ were negligible. Based upon the physician-diagnosed complications, diabetic subjects were sub-divided into CP (cardiac patients), NP (nephropathy patients), RP (retinopathy patients) and HP (hypertensive patients). Among these groups, non-significant differences in clinical and biochemical profiles were acquired, an observation that can be justified by the fact that most of the patients were either in initial complication phases or were using oral hypoglycemic medications. Therefore, data was simplified and presented as case and control participants. 
Table 1: Clinical and biochemical profile

\begin{tabular}{|c|c|c|c|}
\hline Parameters & $\begin{array}{l}\text { Diabetic group } \\
\quad(n=150)\end{array}$ & $\begin{array}{l}\text { Control group } \\
\quad(\mathrm{n}=100)\end{array}$ & $P$ value \\
\hline \multicolumn{4}{|l|}{ Clinical } \\
\hline Age (years) & $46.4 \pm 3.5$ & $46.8 \pm 4.4$ & $>0.05$ \\
\hline Gender (Male/Female) & $80 / 70$ & $53 / 47$ & - \\
\hline BMI $\left(\mathrm{kg} / \mathrm{m}^{2}\right)$ & $35.3 \pm 10.7$ & $22.9 \pm 5.0$ & $<0.05$ \\
\hline sBP (mm Hg) & $149 \pm 13$ & $123 \pm 12$ & $<0.05$ \\
\hline dBP (mm Hg) & $83 \pm 7$ & $75 \pm 8$ & $<0.05$ \\
\hline \multicolumn{4}{|l|}{ Biochemical } \\
\hline $\mathrm{FG}(\mathrm{mg} / \mathrm{dL})$ & $144 \pm 6.38$ & $83 \pm 5.21$ & $<0.05$ \\
\hline HbAlc (\%) & $7.13 \pm 0.58$ & $4.46 \pm 0.49$ & $<0.05$ \\
\hline Vitamin D (mg/dL) & $14.46 \pm 1.29$ & $23.87 \pm 3.16$ & $<0.05$ \\
\hline \multicolumn{4}{|l|}{ Liver Function Tests } \\
\hline Total B (mg/dL) & $1.02 \pm 0.52$ & $1.09 \pm 0.39$ & 0.53 \\
\hline Direct B (mg/dL) & $0.98 \pm 0.36$ & $0.93 \pm 0.31$ & 0.83 \\
\hline $\operatorname{ALT}(\mathrm{mg} / \mathrm{dL})$ & $69.86 \pm 14.67$ & $71.88 \pm 13.90$ & 0.32 \\
\hline $\operatorname{AST}(\mathrm{mg} / \mathrm{dL})$ & $34.54 \pm 17.23$ & $37.77 \pm 18.01$ & 0.29 \\
\hline $\operatorname{ALP}(\mathrm{mg} / \mathrm{dL})$ & $51.87 \pm 11.27$ & $51.24 \pm 11.05$ & 0.99 \\
\hline \multicolumn{4}{|l|}{ Renal Function Tests } \\
\hline BUN (mg/dL) & $39.57 \pm 7.29$ & $13.79 \pm 5.71$ & $<0.05$ \\
\hline Creatinine (mg/dL) & $2.18 \pm 0.36$ & $0.49 \pm 0.40$ & $<0.05$ \\
\hline Uric acid (mg/dL) & $7.01 \pm 0.88$ & $3.00 \pm 0.63$ & $<0.05$ \\
\hline \multicolumn{4}{|l|}{ Lipid Profile } \\
\hline Cholesterol (mg/dL) & $276.38 \pm 29.54$ & $145.09 \pm 12.87$ & $<0.05$ \\
\hline LDL-C (mg/dL) & $169.64 \pm 11.37$ & $65.52 \pm 13.73$ & $<0.05$ \\
\hline HDL-C (mg/dL) & $37.41 \pm 3.95$ & $63.02 \pm 13.26$ & $<0.05$ \\
\hline TG (mg/dL) & $453.05 \pm 147.22$ & $175.14 \pm 8.02$ & $<0.05$ \\
\hline
\end{tabular}

Data expressed as mean $\pm \mathrm{SD}$ (standard deviation), \% or $\mathrm{n}$ (number) unless otherwise indicated, $\mathrm{P}<0.05$ : significant. BMI: body mass index, $\mathrm{sBP}$ : systolic blood pressure, dBP: diastolic blood pressure, FG: fasting glucose, HbA1c: glycated hemoglobin, Total B: total bilirubin, Direct B: direct bilirubin, ALT: alanine transaminase, AST: aspartate transaminase, ALP: alkaline phosphatase, BUN: blood urea nitrogen, LDL-C: low density lipoprotein cholesterol, HDL-C: high density lipoprotein cholesterol, TG: triglycerides

\section{BsmI polymorphisms}

After amplification of intron 8 by PCR (figure 1a), heterozygosity of intron 8 was confirmed by enzymatic digestion (Figure 1b). Figure 1a-b showed typical results in current study that correlate with previously studied results. It was performed to check the action of restriction enzyme. Bsm I polymorphisms among T2DM complications groups were scored in figures 3-5.

Three enzymatic digested fragments of BsmI (76,115 and $191 \mathrm{bp}$ ) indicated heterozygosity (Bb) of BsmI genotype. Differences of $B s m I$ genotypes of VDR gene were significant between T2DM and normal groups $(p<0.01)$. No substantial association was found between biochemical parameters and $B s m I$ restriction site $(\mathrm{p}>0.01)$. 


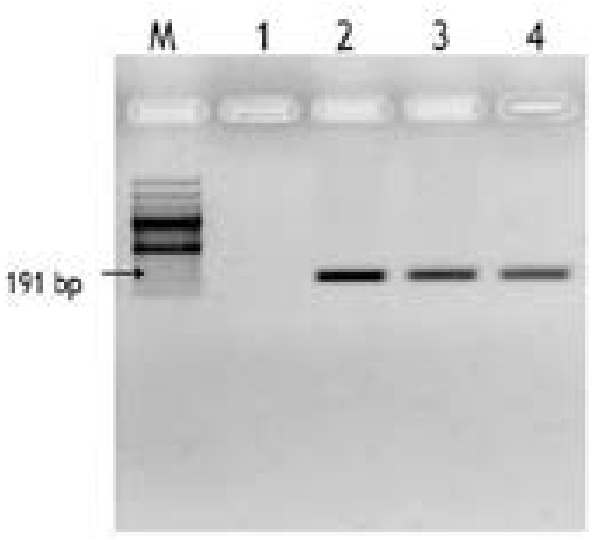

(a)

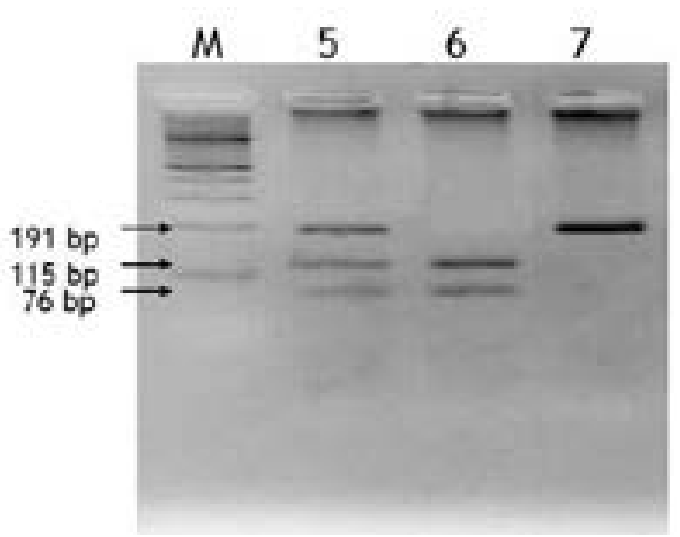

(b)

Figure 1(a-b): a: Electrophoresis of a 2\% agarose gel with intron 8 PCR product loaded; 1 - negative control; 2, 3 and 4 - intron 8 fragment with 191 bp. b: Electrophoresis of a 3\% agarose gel with $B s m I$ enzymatic digestion of $V D R$ intron 8; 5 - heterozygous Bb genotype (76, 115 and $191 \mathrm{bp}$ ); 6 - homozygous bb genotype (76 and $115 \mathrm{bp}$ ); 7 - homozygous BB genotype (191 bp)

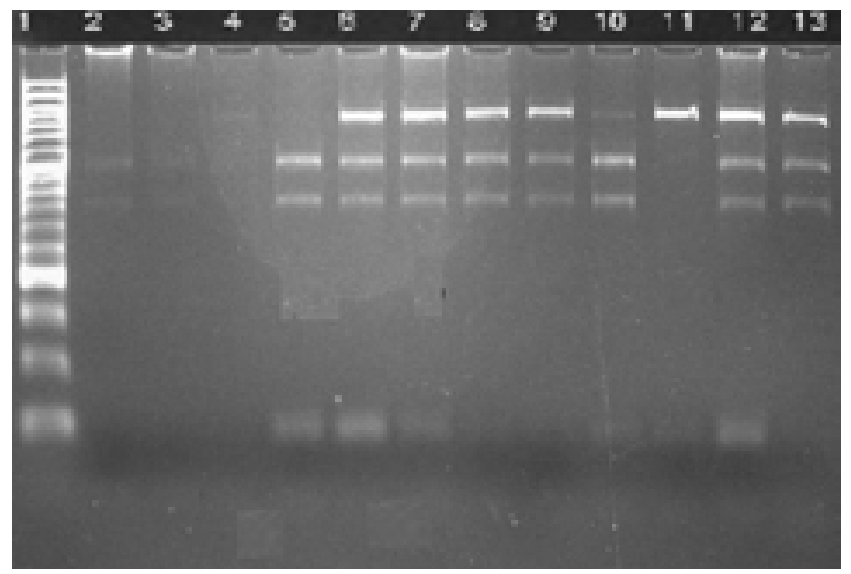

Figure 2: VDR gene BsmIdigestion polymorphism products (cardiac group \& hypertensive patients)

Lane 11 have BB homozygous PCR-RFLP product. Lane 5,6,7,8,9,10,11\& 12 have $\mathrm{Bb}$ heterozygous PCR-RFLP products. Lane 5 has bb homozygous PCR-RFLP products of $175 \mathrm{bp}$. Lane 1 consist of ladder $100 \mathrm{bp}$. 


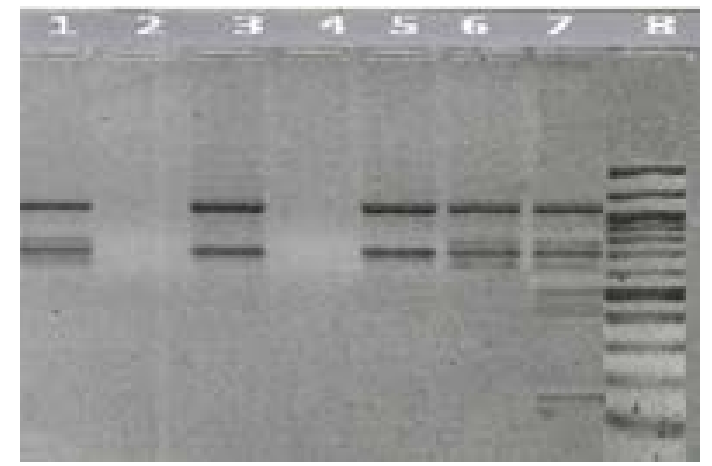

Figure 3: VDR gene BsmI digestion polymorphism products (nephropathy patients group)

Lane 8 : ladder $100 \mathrm{bp}$, lane; 1,3,5,6 and 7 have $B s m$

Idigestion PCR-RFLP product BB $823 \mathrm{bp}$, lane ;1,3,5,6 and

7 consists $648 \mathrm{bp}$ product $\mathrm{Bb}$, lane 7 has bb product of $175 \mathrm{bp}$.

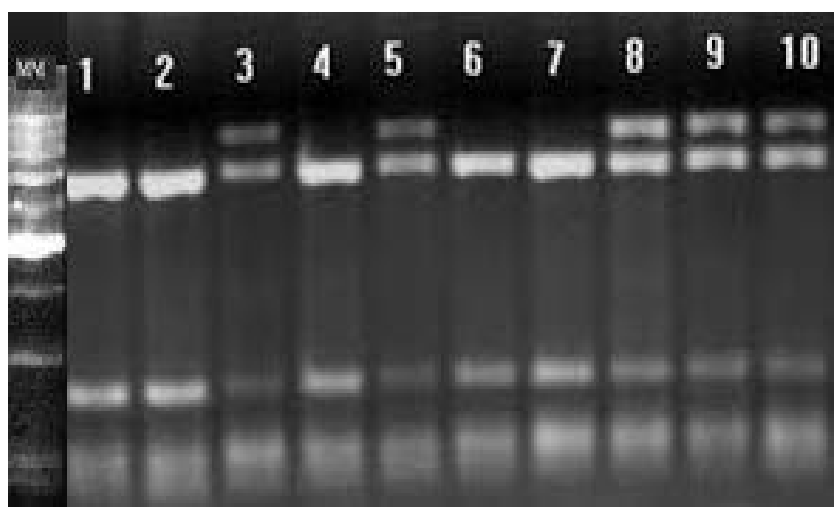

Figure 4: VDR gene BsmIdigestion polymorphism products (retinopathy patients group)

Lane M; Ladder of 100bp. Lane 3,5,8,9 \& 10 consist fragment BB of $823 \mathrm{bp}$. Lane 1,2,3,4,5,6,7,8,9 and 10 consist of $\mathrm{Bb}$ fragment of $648 \mathrm{bp}$. Lane 1,2,3,4,5,6,7,8,9 and 10 consist of fragment $\mathrm{bb}$ of $175 \mathrm{bp}$.

Distribution of genotype allele frequencies and carriage rate of Bsm I among diabetic patients, T2DM sub-groups and control group was non-significant (table 2). Effect of VDR gene polymorphisms on metabolic parameters in terms of probability to clarify their association underlying the diabetic complications are mentioned in table 3. VDR gene $B s m \mathrm{I}$ polymorphism was related non-significantly $(p>0.05)$ to the diabetic complications in the present study. 
Table 2: Distribution of genotype allele frequencies and carriage rate of $\mathrm{Bsm} \mathrm{I}$

\begin{tabular}{|c|c|c|c|c|}
\hline \multirow[t]{2}{*}{ Groups } & \multicolumn{3}{|c|}{ Genotypes } & \multirow[t]{2}{*}{ Total } \\
\hline & bb & $\mathbf{B b}$ & BB & \\
\hline \multirow[t]{2}{*}{ Control } & 2 & 64 & 34 & 100 \\
\hline & $2.0 \%$ & $64.0 \%$ & $34.0 \%$ & $100.0 \%$ \\
\hline \multirow[t]{2}{*}{ Diabetic } & 4 & 119 & 27 & 150 \\
\hline & $2.7 \%$ & $79.3 \%$ & $18.0 \%$ & $100.0 \%$ \\
\hline \multirow[t]{2}{*}{$\mathrm{CP}$} & 3 & 59 & 18 & 80 \\
\hline & $3.8 \%$ & $73.8 \%$ & $22.5 \%$ & $100.0 \%$ \\
\hline \multirow[t]{2}{*}{ NP } & 0 & 18 & 2 & 20 \\
\hline & $0.0 \%$ & $90.0 \%$ & $10.0 \%$ & $100.0 \%$ \\
\hline \multirow[t]{2}{*}{$\mathrm{RP}$} & 0 & 19 & 1 & 20 \\
\hline & $0.0 \%$ & $95.0 \%$ & $5.0 \%$ & $100.0 \%$ \\
\hline \multirow[t]{2}{*}{ HP } & 1 & 23 & 6 & 30 \\
\hline & $3.3 \%$ & $76.7 \%$ & $20.0 \%$ & $100.0 \%$ \\
\hline \multirow[t]{2}{*}{ Total } & 6 & 183 & 61 & 250 \\
\hline & $2.4 \%$ & $73.2 \%$ & $24.4 \%$ & $100.0 \%$ \\
\hline
\end{tabular}

Table 3: Probability values for the association of biochemical parameters and BsmIgenotypes

\begin{tabular}{l|l|llll}
\hline \multirow{2}{*}{ Parameters } & Control & CP & NP & RP & HP \\
& & & & & \\
\hline HbA1c & 0.775 & 0.597 & 0.436 & 0.256 & 0.376 \\
Vitamin-D & 0.334 & 0.592 & 0.165 & 0.858 & 0.279 \\
T. bilirubin & 0.810 & 0.999 & 0.263 & 0.601 & 0.585 \\
D. bilirubin & 0.850 & 0.871 & 0.841 & 0.037 & 0.495 \\
ALT & 0.229 & 0.064 & 0.694 & 0.051 & 0.595 \\
AST & 0.399 & 0.291 & 0.131 & 0.577 & 0.870 \\
ALP & 0.138 & 0.180 & 0.136 & 0.334 & 0.622 \\
BUN & 0.257 & 0.855 & 0.205 & 0.403 & 0.123 \\
Creatinine & 0.536 & 0.137 & 0.620 & 0.868 & 0.658 \\
Uric acid & 0.336 & 0.989 & 0.426 & 0.422 & 0.717 \\
Cholesterol & 0.335 & 0.750 & 0.633 & 0.966 & 0.628 \\
LDL-C & 0.563 & 0.358 & 0.782 & 0.641 & 0.369 \\
HDL-C & 0.763 & 0.988 & 0.178 & 0.954 & 0.719 \\
TG & 0.206 & 0.629 & 0.562 & 0.914 & 0.969 \\
\hline
\end{tabular}

Data expressed as $p-$ value

CP: cardiac patients, NP: nephropathy patients, RP: retinopathy patients, HP: hypertensive patients, HbA1c: glycated hemoglobin, T. bilirubin: total bilirubin, D. bilirubin: direct bilirubin, ALT: alanine transaminase, AST: aspartate transaminase, ALP: alkaline phosphatase, BUN: blood urea nitrogen, LDL-C: low density lipoprotein cholesterol, HDL-C: high density lipoprotein cholesterol, TG: triglycerides 


\section{Discussion}

Although numerous genes have role in T2DM, ${ }^{24,25}$ VDR gene plays a dominant role in onset and progression of T2DM. ${ }^{11,14,26} B s m$ I polymorphism found in intron 8 of VDR gene may be involved in pathogenesis of T2DM. ${ }^{27}$ Prevalence of vitamin D deficiency in T2DM group was higher as compared to control subjects, showing significant association of Bsm I with T2DM in the present study. However, Santos et al. ${ }^{27}$ observed conflicting results in Brazilian population. Contrary to current findings, Dilmec et al. ${ }^{14}$ found significant association of $B s m \mathrm{I}$ to T2DM onset. While Israni et al. ${ }^{28}$ suggested potential role of BsmI polymorphisms. Wang et al. ${ }^{30}$ studied significant association of BsmI polymorphism with T2DM onset.

Review of literature indicates conflicting results regarding the impact of VDR gene polymorphisms on T2DM pathogenesis in different populations ${ }^{14,26,30}$ either supporting or contrasting current findings. Heterogeneity in different populations and limited knowledge of underlying mechanism may be responsible for these discrepancies. $^{31,32}$

Statistically non-significant relationship between Bsm I polymorphism and T2DM in current project is supported by earlier study. ${ }^{33}$ This study suggests that the Bsm I may be related with susceptibility to T2DM subjects but genetic contribution of VDR gene polymorphism for the development or existing diabetic complications is not clear. In addition, vitamin D receptor gene consists of many single nucleotide polymorphisms (SNPs). To investigate whether functional changes of VDR gene may be potential risk for T2DM, future studies should focus on population or case-control studies along with family linkage with multiple SNP study ${ }^{34}$

\section{Conflict of interest statement}

We declare that we have no conflict of interest.

\section{References}

1. Hale PJ, López-Yunez AM, Chen JY. Genome-wide meta-analysis of genetic susceptible genes for type 2 diabetes. BMC Syst Biol. 2012; 3: 16. doi: 10.1186/17520509-6-S3-S16

2. Filus A, Trzmiel A, Kuliczkowska-Plaksej J, Tworowska U, Jedrzejuk D, Milewicz A. Relationship between vitamin D receptor BsmI and FokI polymorphisms and anthropometric and biochemical parameters describing metabolic syndrome. Aging Male. 2003; 11(3):134-139. doi: 10.1080/13685530802273426
3. Manchandra PK, Bid HK. Vitamin D receptor and type 2 diabetes mellitus: Growing therapeutic opportunities. Indian J Hum Genet. 2012; 18(3): 274-275. doi: 10.4103/0971-6866.107975

4. Haussler MR, Jurutka PW, Mizwicki M, Norman AW. Vitamin D receptor (VDR)-mediated actions of 1 alpha, $25(\mathrm{OH})$ (2) vitamin D (3): genomic and non-genomic mechanisms. Best Pract Res Clin Endocrinol Metab. 2011; 25(4): 543-559. doi: 10.1016/j.beem.2011.05.010.

5. Vural HC, Maltas E. RT-qPCR assay on the vitamin $\mathrm{D}$ receptor gene in type 2 diabetes and hypertension patients in Turkey. Genet Mol Res. 2012; 11(1): 582-590. doi: 10.4238/2012.March.14.1.

6. Sung CC, Liao MT, Lu KC, Wu CC. Role of vitamin D in insulin resistance. J Biomed Biotechnol. 2012; 634195. doi: 10.1155/2012/634195

7. Christakos SDP, Liu Y, Peng X, Porta A. New insights into the mechanisms of vitamin $\mathrm{D}$ action. J Cell Biochem 2003; 88(4): 695-705. doi: 10.1002/jcb.10423

8. Maestro B, Davila N, Carranza MC, Calle C. Identification of a Vitamin $\mathrm{D}$ response element in the human insulin receptor gene promoter. J Steroid Biochem Mol Biol. 2003; 84(2-3): 223-230. https://doi.org/10.1016/S09600760(03)00032-3

9. Calle C, Maestro B, García MA. Genomic actions of 1, 25- dihydroxyvitamin D3 on insulin receptor gene expression, insulin receptor number and insulin activity in the kidney, liver and adipose tissue of streptozotocine-induced diabetic rats. BMC Mol Biol. 2008; 9(1): 65-77. doi: 10.1186/1471-2199-9-65

10. Speer G, Cseh K, Winkler G, Vargha P, Braun E, Takacs I. Vitamin D and estrogen receptor gene polymorphisms in type 2 diabetes mellitus and in android type obesity. Eur J Endocrinol. 2001; 144(4): 385-389. doi: 10.1530/eje.0.1440385

11. Nosratabadi R, Arababadi MK, Salehabad VA, Shamsizadeh A, Mahmoodi M, Sayadi AR, et al. Polymorphisms within exon 9 but not intron 8 of the vitamin $\mathrm{D}$ receptor are associated with the nephropathic complication of type-2 diabetes. Int J Immunogenet. 2010; 37(6): 493497. doi: 10.1111/j.1744-313X.2010.00953.x

12. Al-Daghri NM, Al-Attas O, Alokail MS, Alkharfy KM, Draz HM, Agliardi C, et al.Vitamin D receptor gene polymorphisms and HLA DRB1*04 cosegregation in Saudi type 2 diabetes patients. J Immunol. 2012; 188(3): 1325-1332. doi: 10.4049/jimmunol.1101954

13. Ortlepp JR, Metrikat J, Albrecht M, von Korff A, Hanrath P, Hoffmann P. The vitamin D receptor gene 
variant and physical activity predicts fasting glucose levels in healthy young men. Diabetes Med. 2002; 20(6): 451-454. doi: 10.1046/j.1464-5491.2003.00971.x

14. Dilmec F, Uzer E, Akkafa F, Kose E, van Kuilenburg AB. Detection of VDR gene ApaI and TaqI polymorphisms in patients with type 2 diabetes mellitus using PCR-RFLP method in a Turkish population. J Diabetes Complications. 2010; 24(3): 186-191. doi: 10.1016/j.jdiacomp.2008.12.002

15. Malecki MT, Frey J, Moczulski D, Klupa T, Kozek E, Sieradzki J. VDR gene polymorphisms and association with type 2 diabetes mellitus in a Polish population. Exp Clin Endocrinol Diabetes. 2003; 111(8): 505-509. doi:10.1055/s-2003-44711

16. Oh JY, Barrett-Connor E. Association between vitamin $\mathrm{D}$ receptor polymorphism and type 2 diabetes or metabolic syndrome in community-dwelling older adults: the Rancho Bernardo study. Metabolism. 2002; 51(3): 356359. https://doi.org/10.1053/meta.2002.29969

17. Anuradha CV. Phytochemicals targeting genes relevant for type 2 diabetes. Can J Physiol Pharmacol. 2013; 91(6): 397-411. https://doi.org/10.1139/cjpp-2012-0350 18. Riaz H, Finlayson A, Bashir S, Hussain S, Mahmood S, Malik F, et al.Prevalence of Vitamin D deficiency in Pakistan; implications for the future. Expert Rev Clin Pharmacol. 2016;9(2):329-338. doi: 10.1586/17512433.2016.1122519 19. Iqbal R, Khan AH. Possible causes of vitamin D deficiency (VDD) in Pakistani population residing in Pakistan. J Pak Med Assoc. 2010; 60(1): 1-2. PMID:20055268 20. Roomi MA, Farooq A, Ullah E, Lone KP. Hypovitaminosis $\mathrm{D}$ and its association with lifestyle factors. Pak J Med Sci. 2015; 31(5): 1236-1240. doi: 10.12669/ pjms.315.7196

21. WHO Diabetes Fact sheet No 312. October 2014. Retrieved 25 March 2015.

22. Sambrook JF, Russell DW, Irwin N. Molecular cloning: A laboratory manual, 3rd ed. Cold Spring Harbor Laboratory press, Cold Spring, 2000.

23. Bid HK, Konwar R, Aggarwal CG, Gautam S, Saxena M, Nayak VL. Vitamin D receptor (FokI, BsmI and TaqI) gene polymorphisms and type 2 diabetes mellitus: a North Indian study. Indian J Med Sci. 2009; 63(5):187-194. doi: 10.4103/0019-5359.53164.

24. Puri S, Marwaha RK, Agarwal N, Tandon N, Agarwal R, Grewal K, et al. Vitamin D status of apparently healthy school girls from two different socioeconom- ic strata in Delhi: Relation to nutrition and lifestyle. $\mathrm{Br}$ J Nutr. 2008; 99(4): 876-882. https://doi.org/10.1017/ S0007114507831758

25. Heaney RP, Holick MF. Why the IOM recommendations for vitamin D are deficient? J Bone Miner Res. 2011; 26(3): 457-458. doi: 10.1002/jbmr.328.

26. Neyestani TR, Djazayery A, Shab-Bidar S, Eshraghian MR, Kalayi A, Shariatzadeh N, et al. Vitamin D receptor Fok-I polymorphism modulates diabetic host response to vitamin D intake: need for a nutrigenetic approach. Diabetes Care. 2013; 36(3): 550-556. doi: 10.2337/dc12-0919. 27. Santos BR, Mascarenhas LPG, Satler F, Boguszewski MCS, Spritzer PM. Vitamin D deficiency in girls from South Brazil: A cross-sectional study on prevalence and association with vitamin $\mathrm{D}$ receptor gene variants. $B M C$ Pediatr. 2012; 12(1): 62. doi: 10.1186/1471-2431-12-62.

28. Israni N, Goswami R, Kumar A, Rani R. Interaction of vitamin D receptor with HLA DRB1 0301 in type 1 diabetes patients from North India. PLoS One. 2009; 4(12): e8023. doi: 10.1371/journal.pone.0008023.

29. Wang Q, Xi B, Reilly KH, Liu M, Fu M. Quantitative assessment of the associations between four polymorphisms (FokI, ApaI, BsmI, TaqI) of vitamin D receptor gene and risk of diabetes mellitus. Mol Biol Rep. 2012; 39(10): 9405-9414. doi: 10.1007/s11033-012-1805-7

30. Palomer X, Gonza'lez-Clemente JM, Blanco-Vaca F, Mauricio D. Role of vitamin D in the pathogenesis of type 2 diabetes mellitus. Diabetes Obes Metab. 2008; 10(3): 185-197. doi: 10.1111/j.1463-1326.2007.00710.x.

31. Al-Daghri NM, Al-Attas OS, Alkharfy KM, Khan $\mathrm{N}$, Mohammed AK, Vinodson B, et al. Association of VDR-gene variants with factors related to the metabolic syndrome, type 2 diabetes and vitamin D deficiency. Gene. 2014; 542(2): 129-133. doi: 10.1016/j.gene.2014.03.044 32. Arababadi MK, Nosratabadi R, Hassanshahi G, Yaghini N, Pooladvand V, Shamsizadeh A. Nephropathic complication of type-2 diabetes is following pattern of autoimmune diseases? Diabetes Res Clin Prac. 2010; 87(1): 33-35. doi: 10.1016/j.diabres.2009.09.027.

33. Li L, Wu B, Liu JY, Yang LB. Vitamin D receptor gene polymorphisms and type 2 diabetes: a meta-analysis. Arch Med Res. 2013; 44(3): 235-241. doi: 10.1016/j.arcmed.2013.02.002.

34. Stram DO. Tag SNP selection for association studies. Genet Epid 2004; 27(4): 365-374. doi: 10.1002/gepi.20028 